\title{
Islamic Work Ethics-Based Organizational Citizenship Behavior to Improve the Job Satisfaction and Organizational Commitment of Higher Education Lecturers in Indonesia
}

\author{
Mochamad Vrans Romi ${ }^{1,2}$, Eeng Ahman ${ }^{1}$, Disman $^{1}$, Edi Suryadi $^{1} \&$ Ari Riswanto ${ }^{3}$ \\ ${ }^{1}$ Universitas Pendidikan Indonesia, Bandung, Indonesia \\ ${ }^{2}$ Universitas Jenderal Achmad Yani, Cimahi, Indonesia \\ ${ }^{3}$ Sekolah Tinggi Keguruan dan Ilmu Pendidikan PGRI, Sukabumi, Indonesia \\ Correspondence: Mochamad Vrans Romi, Universitas Pendidikan Indonesia, J1. Dr. Setiabudi No.229, Isola, \\ Sukasari, Bandung, Jawa Barat 40154, Indonesia.
}

Received: December 10, 2019

Accepted: December 30, 2019

Online Published: January 7, 2020

doi:10.5430/ijhe.v9n2p78

URL: https://doi.org/10.5430/ijhe.v9n2p78

\begin{abstract}
Problems of organizational citizenship behavior among academics, especially lecturers, are something relevant in the study of the quality of an organization. The purpose of this study is to analyze the increase in organizational citizenship behavior based on Islamic work ethics, organizational satisfaction and commitment. By collecting data from 365 lecturers from 14 private universities as sample in the city of Bandung, the sampling was taken with proportional random sampling techniques. Data analysis techniques were conducted by using Structural Equation Modeling (SEM) using AMOS. The results of this study revealed the positive effect of Islamic work ethics on organizational citizenship behavior and on organizational commitment, positive but not significant effect of Islamic work ethics on job satisfaction. Islamic work ethic has a positive effect on organizational commitment. Moreover, the findings showed that job satisfaction has a positive and significant effect on organizational citizenship behavior. However, job satisfaction has a positive but not significant effect on organizational commitment. In practice, this study encourages private university management to improve work ethics and job satisfaction of lecturers, which in turn can influence organizational citizenship behavior and organizational commitment of lecturers.
\end{abstract}

Keywords: organizational citizenship behavior, Islamic work ethics, job satisfaction, organizational commitment

\section{Introduction}

Improving the quality of work of employees in an organization cannot be separated from the rules and norms that apply in the work environment. In addition, in some countries with high religiosity, such as Indonesia with Islamic values, employees must also obey the ethics that have been arranged in the teachings of their respective religions. Islamic work ethics is a form of ethical management that influences individual behavior in acting and behaving. The sustainability of an organization is inseparable from the involvement of individuals who have positive behavior and good synergy (Organ et al., 2006; Farsi et al., 2015). Katz (1964) stated that the requirements of an organization to run effectively and efficiently in its management ie every individual in the organization must remain and persist in managing the organization until the achievement of high levels of job satisfaction. Job satisfaction is the attitude of every individual who shows the difference between the award received with the belief how much employees believe in what they should receive. Attitudes and behaviors of individuals in the workplace will have a very large impact on the level of attendance, turnover, innovation produced, employee satisfaction, loyalty to the organization, this will also affect the level of productivity and efficiency of resources owned by an organization so that the behavior encourages achieving maximum performance (Chahal \& Mehta, 2010; Riswanto et al., 2019).

Extra performance behavior or better known as organizational citizenship behavior is a series of work that is voluntarily performed by an employee in an organization where the employee's behavior exceeds the basic work requirements that have been determined or exceeds the work standards set in the organization (Carmeli \& Josman, 2006). Organizational citizenship behavior is also a behavior that greatly helps an organization in maximizing performance achievement with the help of employees who are willing to work more than formal tasks and even are 
willing to provide performance results that exceed the expectations of the organization, especially in terms of organizational commitment (Organ et al., 2006).

Organizational commitment can be seen from how much the desire of employees in an organization to survive managing the organization together for the achievement of organizational goals, commitment is also a strong desire and belief of individuals in accepting strong values and norms among workers in the long run, where there are experiences of individual success both personally and in work groups (Khalid et al., 2018). Contributions from employees who have good behavior for the benefit of their organizations must also have an educational institution in Indonesia, including in private universities (Suparjo., \& Sunarsih, 2018; Pudjiarti, 2018). Nowadays, private universities are competing to continue their efforts to improve the ranking of tertiary institutions both nationally and internationally. The achievement of the objectives of the organization is inseparable from the role of the members of the organization. By taking the research object of private universities in Bandung city, Indonesia, this study is conducted at lecturers in educational institutions at private universities to examine the effect of Islamic work ethics on organizational citizenship behavior and organizational commitment of private university lecturers in Bandung, Indonesia, by exploring the mediating variables of job satisfaction.

\section{Literature Review}

\subsection{Islamic Work Ethics (IWE)}

Islamic work ethics are based on Islamic sacred texts which are orientations that influence and involve the participation of a Muslim in carrying out his work (Mohammad et al., 2016). In work ethics, Islam views work as a means to improve life economically, socially and psychologically based on faith in God (Sehhat et al., 2015). Some behaviors are ethically suggested in Islamic teachings, which include at least four concepts in Islamic work ethics namely business, competition, transparency, and responsible behavior. The main goal of Islamic work ethics is to spread affection to all beings who are the beliefs of a muslim in his life (Triyuwono and Wan, 2000).

\subsection{Organizational Citizenship Behavior (OCB)}

The study of Organizational Citizenship Behavior (OCB) in an organization is an interesting thing to study. OCB is a discretionary behavior of the individual which does not explicitly and indirectly receive an award from the fornal reward system and which as a whole encourages the functions in the organization to run effectively and efficiently (Organ et al., 2006). Members of an organization that has a high level of OCB will make the organization superior to other organizations in terms of the performance of the organization it achieves (Robbins, 2009), OCB indicators used are the components proposed by Luthans (2006), Szabó et al. (2018), and Sun et al. (2018), consisting of altruism, courtesy, sportsman-ship, conscientiousness and civic virtue.

\subsection{Job Satisfaction}

Job satisfaction is closely related to the general attitude of a worker, where the employee shows the difference between the number of awards received and the amount believed to be received by the worker (Robbins, 2009). Job satisfaction is the attitude of an individual both positive and negative of an employee towards their work (Baron \& Greenberg, 2003), job satisfaction is also defined as one's feelings, thoughts and actions, which is one's attitude towards work in an organization (Vecchio, 2005).

\subsection{Organizational Commitment}

Organizational commitment is a strong desire to remain a member of the organization where members of the organization strive to work according to the wishes and beliefs of the organization (Wibowo, 2014), organizational commitment is also part of employee loyalty to the organization and ongoing processes in which organizational members show training for the organization and the achievement of organizational values and goals (Luthans, 2006). Organizational commitment can also be defined where an employee who maintains his membership in the organization while still trying hard in his work in order to achieve organizational goals (Robbins, 2009).

Based on the literature review from previous studies, the following hypotheses were proposed in this study:

H1: There is a significant influence between Islamic work ethics and OCB.

H2: There is a significant relationship between Islamic work ethics and job satisfaction.

H3: There is a significant relationship between Islamic work ethics and organizational commitment.

H4: There is a significant relationship between job satisfaction and $O C B$

H5: There is a significant relationship between job satisfaction and organizational commitment 


\section{Conceptual Framework}

Based on the results of several empirical studies and literature reviews that have been described, the researchers compiled the research model as follows:

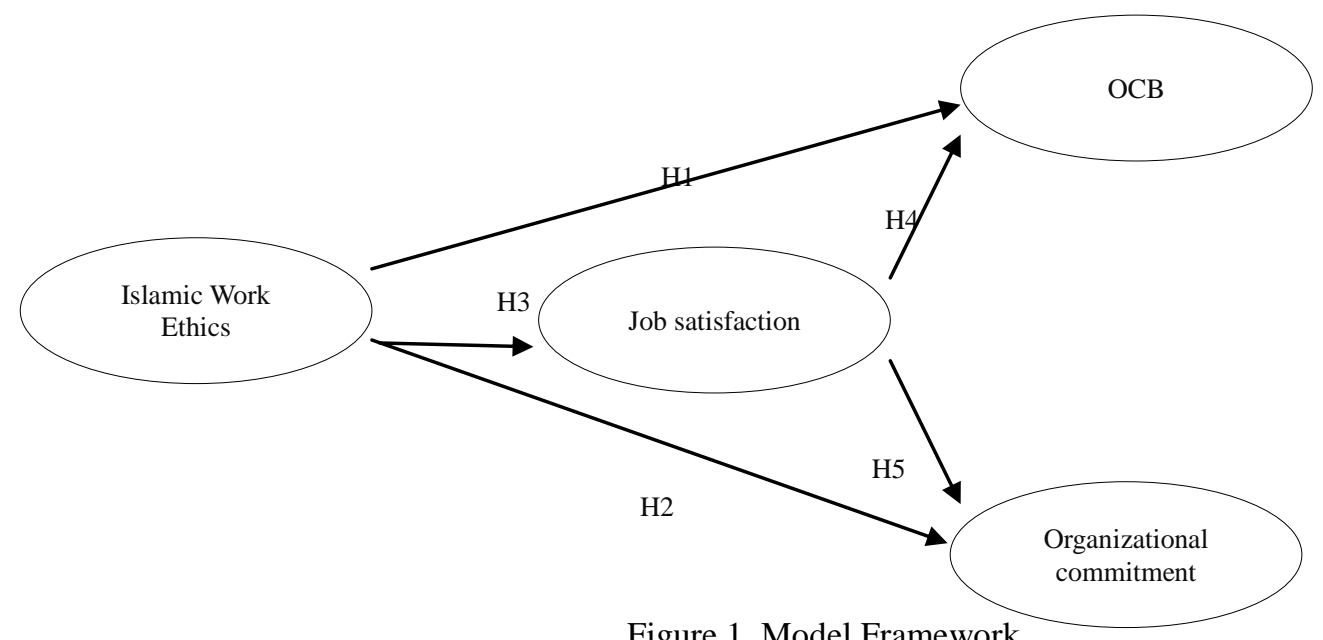

\section{Methodology}

In this study the sample is 365 lecturers from 14 private universities in the city of Bandung. The sampling technique uses proportional random sampling.

As for variable measurements, Islamic work ethics in this study refers to the extent to which work impulses relate to lecturers' religiosity values, especially work values emphasized by Islam. The constructs developed in this study were adopted from Chanzanagh and Akbarnejad (2011). This variable is indicated by 7 constructs which include work intention, trusteeship, work type, work for Islamic community, justice and fairness, cooperation \& collaboration, and work as the only source of ownership. The job satisfaction variable refers to the extent to which employees are involved in decision making, organizational access and support and appreciation for their performance as a lecturer in tertiary institutions. Job satisfaction is proxied by 6 constructs which include involvement in decision making, rewards, access to information, active encouragement from university leaders, support from administrative staff functions, and total satisfaction.

The variable organizational citizenship behavior in this study refers to the definition developed by Organ et al. (2006) who developed a theoretical concept of employee voluntary commitment to work outside of contractual tasks. In this study, operationally, OCB refers to the extent to which private university lecturers want to work voluntarily outside the tasks in their job description. The OCB variable in this study was adopted from the construct developed by Luthans (2006), Szabó et al. (2018), and Sun et al. (2018) which includes altruism, conscientiousnes, courtesy, sportmanship and civic virtue.

Organizational commitment variable in this study refers to the definition developed by Meyer and Allen (1991). Operationally, the commitment in this study is defined as the tendency of private university lecturers to be serious in completing their assignments. This variable is proxied by several indicators which include visibility, firmness, behavior determination and personal will.

The instruments used in data collection in this study were questionnaires that had been distributed to 14 universities online and were filled directly on the questionnaire sheets, questionnaires were distributed to respondents who had met the criteria. The scale used is a Likert Scale with a range of 1 (strongly disagree) - 7 (strongly agree). The data analysis technique used in this research is Structural Equation Modeling (SEM) with Amos program tools

\section{Results}

The number of samples in this study were 365 private university lecturers in Bandung, Indonesia. From this number, descriptive analysis through demographic characteristics of the respondents showed that the majority were women as many as $233(64 \%)$. In terms of age, most respondents aged 31-40 years amounted to 172 people (47\%), followed by respondents aged 41-50 people as many as 94 people (26\%). In terms of education, two-thirds of all samples were graduated from master degree as many as 278 people (76\%). In terms of position, the majority were assistants as many as 166 respondents (45\%), followed by senior lector and lector, respectively 67 and 57 people. 
Table 1. Demographic character of the respondent

\begin{tabular}{cccc}
\hline Characteristics & Classification & Frequency & $\%$ \\
\hline Gender & Male & 132 & $36 \%$ \\
& Female & 233 & $64 \%$ \\
Age & $20-30$ & 56 & $15 \%$ \\
& $31-40$ & 172 & $47 \%$ \\
& $41-50$ & 94 & $26 \%$ \\
Education & $>51$ & 43 & $12 \%$ \\
& Bachelor & - & - \\
& Master & 278 & $76 \%$ \\
Functional & PhD & 87 & $24 \%$ \\
& No Position & 45 & $12 \%$ \\
& Assistant & 166 & $45 \%$ \\
& Lecturer & 57 & $16 \%$ \\
& Senior Lecturer & 67 & $18 \%$ \\
& Professor & 30 & $8 \%$ \\
& & & \\
& & &
\end{tabular}

Next is hypothesis testing. The testing of 5 hypotheses of this study was carried out based on the results of the analysis of causality relationships between research constructs, with the following detailed results.

Table 2. Standardized and unstandardized measurements and Weight regression in the Structural Model

\begin{tabular}{cccccc}
\hline \multicolumn{3}{c}{ Hypothesis } & Estimate & $\mathrm{P}$ & Results \\
\hline IWE & $\rightarrow$ & OCB & 0.577 & 0.000 & Significant \\
IWE & $\rightarrow$ & JS & 0.154 & 0.143 & Insignificant \\
IWE & $\rightarrow$ & OC & 0.355 & 0.000 & Significant \\
JS & $\rightarrow$ & OCB & 0.165 & 0.053 & Significant \\
JS & $\rightarrow$ & OC & 0.080 & 0.403 & Insignificant \\
\hline
\end{tabular}

Note: IWE = Islamic work ethics; $\mathrm{JS}=$ job satisfaction; $\mathrm{OCB}=$ organizational citizenship behaviour $=\mathrm{OC}=$ organizational commitment

In testing the influence of Islamic work ethics on organizational citizenship behavior (OCB), the results of hypothesis testing prove that Islamic work ethics have a positive and significant effect on organizational commitment. This means that in Islamic education especially relating to the behavior of every Muslim in acting according to the ethics that are learned is a compulsory worship. An employee's ethics in working will lead to the intentions of all their actions are aimed at worship and willingly willing to help his coworkers, which means by improving Islamic work ethics, it also increases the organizational citizenship behavior of the employee. The findings of this study are in line with the results of research conducted by Wahab et al. (2016), Sehhat et al. (2015), de Clercq et al. (2017), and Khadijah et al. (2015).

In testing the influence of Islamic work ethics on satisfaction, the results of hypothesis testing indicate that Islamic work ethics have a significant positive effect on job satisfaction. This means that Islamic work ethics does not directly affect job satisfaction because satisfaction is often interpreted only in material terms. The results of this study are not in line with research conducted by several studies (Farsi et al., 2015; Mohammad and Quoquab, 2016; Purnama, 2017; Ahmad et al., 2019; Khalid et al., 2018).

The results of hypothesis testing prove that Islamic work ethics have a positive and significant effect on organizational commitment. This means that in organizing so that the commitment of each member of his organization can increase, Islamic work ethics can help encourage the achievement of increased commitment from employees to jointly contribute to the achievement of organizational goals. The findings of this study are in line with the results of research conducted by several previous studies (Pio and Tampi, 2018; Aldulaimi, 2016; Tufail et al., 2017; Mohammad et al., 
2016).

In testing the effect of job satisfaction on organizational citizenship behavior, the results of hypothesis testing show job satisfaction has a positive and significant effect on OCB, where if individuals in an organization feel satisfied with what is provided by the company, the level of organizational citizenship behavior will increase marked by more effective and efficient organizational achievement results from employees who have behaved properly for the organization. The findings of this study are in line with the results of research conducted by (Bolino et al., 2015; Alhyasat, 2012; Szabó et al., 2018; Mo and Shi, 2017).

Table 3. Analysis of direct effects, indirect effects and total effects

\begin{tabular}{ccccccc}
\hline & \multicolumn{3}{c}{ IWE } & \multicolumn{3}{c}{ JS } \\
\hline & $\begin{array}{c}\text { direct } \\
\text { effects }\end{array}$ & $\begin{array}{c}\text { indirect } \\
\text { effects }\end{array}$ & Total & direct effects & $\begin{array}{c}\text { indirect } \\
\text { effects }\end{array}$ & Total \\
JS & 0.152 & - & 0.152 & - & - & - \\
OCB & 0.567 & 0.026 & 0.593 & 0.163 & - & 0.163 \\
OC & 0.355 & 0.012 & 0.367 & 0.080 & - & 0.080
\end{tabular}

Note: IWE= Islamic work ethics; JS= job satisfaction; $\mathrm{OCB}=$ organizational citizenship behaviour $=\mathrm{OC}=$ organizational commitment

In testing the effect of job satisfaction on organizational commitment, the results of hypothesis testing indicate that job satisfaction is not a significant positive effect on organizational commitment. The results of this study indicate that job satisfaction is not always have larger influence with indirect effect in increasing the commitment of members of the organization in terms of affective, continuance and normative commitment. The results of this study are not consistent with previous studies (Brockner et al., 2006; Ma et al., 2018; Chan and Lai, 2017; Harris et al., 2018; Klotz et al., 2018). The results of further testing by testing the role of mediation indicate that job satisfaction only acts as a mediator in the relationship of Islamic work ethics with OCB and in the relationship of Islamic work ethics with organizational commitment. Furthermore, based on testing of mediation variables, it is evident that the job satisfaction variable is not a full mediating variable as stated by several findings (Harvey et al., 2018; Miao et al., 2018).

The results of this study prove that Islamic work ethics influence the formation of organizational citizenship behavior and job satisfaction in the private tertiary environment. This means increasing and deepening religious values, mainly related to work values emphasized in Islam such as work intention, trusteeship, work type, work for Islamic community, justice and fairness, cooperation and collaboration, and work as the only source of ownership is more likely to have a positive effect on OCB improvement and lecturer job satisfaction. In the context of empirical findings in the relationship between Islamic work ethics and organizational citizenship, some aspects that can be improved are improving lecturers' access to organizational knowledge and resources, organizational support for lecturers to develop teaching capacity and knowledge enhancement, and active involvement of lecturers in decision making organizational In addition, support in technical works from administrative and managerial staff from university leaders can influence the improvement of lecturers' behaviors to do work outside of contractual assignments.

\section{Conclusion}

This study seeks to examine the effect of Islamic work ethics on organizational citizenship behavior and organizational commitment of private university lecturers in Bandung, Indonesia, by exploring the mediating variables of job satisfaction. The results show that Islamic work ethic has a significant positive effect on organizational citizenship behavior. Furthermore, Islamic work ethics have a positive but not significant effect on job satisfaction. The third finding indicates that Islamic work ethics have a significant positive effect on organizational commitment. In terms of mediating variables, the results revealed that job satisfaction had a significant positive effect on organizational citizenship behavior. However, job satisfaction has a positive and not significant effect on organizational commitment.

Theoretically, these results indicate that Islamic work ethics is felt to be beneficial in increasing the organizational commitment of lecturers and OCBs in private universities. In addition, in practice, the results encourage the organization of private tertiary institutions to strengthen Islamic work ethics among lecturers, and increase efforts to increase lecturer job satisfaction. The limitation of this study is that it was carried out cross-sectionally, and not on a longitudinal basis. Future studies are expected to further examine the effect of Islamic work ethics on improving $\mathrm{OCB}$ and lecturer organizational commitment in the environment of private and public tertiary institutions by 
involving a broader sample. In addition, further research is also expected to be able to analyze the influence of Islamic work ethics on lecturer performance, and conduct research with longitudinal designs to prove the influence of Islamic work ethics on improving lecturer performance, both on public or private campuses.

\section{References}

Aldulaimi, S. H. (2016). Fundamental Islamic perspective of work ethics. Journal of Islamic Accounting and Business Research, 7(1), 59-76. https://doi.org/10.1108/JIABR-02-2014-0006

Alhyasat, K. M. K. (2012). The role of Islamic work ethics in developing organizational citizenship behavior at the Jordanian Press Foundations. Journal of Islamic Marketing, 3(2), 139-154. https://doi.org/10.1108/17590831211232555

Baron, A. R., Greenberg, J. (2003). Organizational Behaviour in Organization: Understanding and managing the human side of work. Prentice Hall.

Bolino, M. C., Hsiung, H. H., Harvey, J., \& LePine, J. A. (2015). “Well, I'm tired of tryin'!” Organizational citizenship behavior and citizenship fatigue. Journal of Applied Psychology, 100(1), 56-74. https://doi.org/10.1037/a0037583

Brockner, J. et al. (2006). Commentary on "radical HRM innovation and competitive advantage: The Moneyball story”. Human Resource Management, 45(1), 127-145. https://doi.org/10.1002/hrm.20100

Carmeli, A., \& Josman, Z. E. (2006). The relationship among emotional intelligence, task performance, and organizational citizenship behaviors. Human performance, 19(4), 403-419. https://doi.org/10.1207/s15327043hup1904_5

Chahal, H., \& Mehta, S. (2010). Antecedents and consequences of organizational citizenship behavior: A conceptual framework in reference to health care sector. Journal of Services Research, 10(2), 25-44. https://doi.org/10.1007/s11482-016-9484-5

Chan, S. H. J., \& Lai, H. Y. I. (2017). Understanding the link between communication satisfaction, perceived justice and organizational citizenship behavior. Journal of business research, 70, 214-223. https://doi.org/10.1016/j.jbusres.2016.08.017

Chanzanagh, H. E., \& Akbarnejad, M. (2011). The meaning and dimensions of Islamic work ethic: initial validation of a multidimensional IWE in Iranian society. Procedia-Social and Behavioral Sciences, 30, 916-924. https://doi.org/10.1016/j.sbspro.2011.10.178

De Clercq, D., Rahman, Z., \& Haq, I. U. (2019). Explaining helping behavior in the workplace: The interactive effect of family-to-work conflict and Islamic work ethic. Journal of Business Ethics, 155(4), 1167-1177. https://doi.org/10.1007/s10551-017-3541-3

Farsi, J. Y. et al. (2015). Investigating the Relationship between Islamic Work Ethics and Organizational Commitment and Its Components A Case Study of Gilan Province Police Employees Razie poorabbasi shiraz. Jurnal UMP Social Sciences and Technology Management, 3(2), 238-244.

Harris, C. M., Lavelle, J. J., \& McMahan, G. C. (2018). The effects of internal and external sources of justice on employee turnover intention and organizational citizenship behavior toward clients and workgroup members. The International Journal of Human Resource Management, 1-24. https://doi.org/10.1080/09585192.2018.1441163

Harvey, J., Bolino, M. C., \& Kelemen, T. K. (2018). Organizational citizenship behavior in the 21st century: How might going the extra mile look different at the start of the new millennium?. Research in Personnel and Human Resources Management, 36, 51-110. https://doi.org/10.1108/S0742-730120180000036002

Katz, D. (1964). The motivational basis of organizational behavior. Behavioral science, 9(2), 131-146. https://doi.org/10.1002/bs.3830090206

Khadijah, A. S., Kamaluddin, N., \& Salin, A. S. A. P. (2015). Islamic work ethics (IWE) practice among employees of banking sectors. Middle-East Journal of Scientific Research, 23(5), 924-931.

Khalid, M. et al. (2018). When and how abusive supervision leads to knowledge hiding behaviors: An Islamic work ethics perspective. Leadership and Organization Development Journal, 39(6), 794-806. https://doi.org/10.1108/LODJ-05-2017-0140 
Klotz, A. C. et al. (2018). Examining the nature, causes, and consequences of profiles of organizational citizenship behavior. Journal of Organizational Behavior, 39(5), 629-647. https://doi.org/10.1002/job.2259

Luthans, F. (2006). Perilaku Organisasi. Yogyakarta: Andi Offset.

Ma, E., Qu, H., Wei, X., \& Hsiao, A. (2018). Conceptualization and operationalization of an altruistic and egoistic continuum of organizational citizenship behavior motivations. Journal of Hospitality \& Tourism Research, 42(5), 740-771. https://doi.org/10.1177/1096348015619412

Meyer, J. P., \& Allen, N. J. (1991). A three-component conceptualization of organizational commitment. Human resource management review, 1(1), 61-89. https://doi.org/10.1016/1053-4822(91)90011-Z

Miao, C., Humphrey, R. H., \& Qian, S. (2018). A cross-cultural meta-analysis of how leader emotional intelligence influences subordinate task performance and organizational citizenship behavior. Journal of World Business, 53(4), 463-474. https://doi.org/10.1016/j.jwb.2018.01.003

Mo, S., \& Shi, J. (2017). Linking ethical leadership to employees' organizational citizenship behavior: Testing the multilevel mediation role of organizational concern. Journal of Business Ethics, 141(1), 151-162. https://doi.org/10.1007/s10551-015-2734-x

Mohammad, J., Quoquab, F., \& Omar, R. (2016). Factors affecting organizational citizenship behavior among Malaysian bank employees: The moderating role of islamic work ethic. Procedia-Social and Behavioral Sciences, 224, 562-570. https://doi.org/10.1016/j.sbspro.2016.05.440

Organ, D. W., Podsakoff, P. M, \& MacKenzie, S. B. (2006) Organizational Citizenship Behavior: Its Nature, Antecedents and Consequences. Beverly Hills, CA: Sage.

Pio, R. J. \& Tampi, J. R. E. (2018). The influence of spiritual leadership on quality of work life, job satisfaction and organizational citizenship behavior. International Journal of Law and Management, 60(2), 757-767. https://doi.org/10.1108/IJLMA-03-2017-0028

Pudjiarti, E. S. (2018). Elements of entrepreneurship in private universities: Organizational change capacity, innovative capability and the performance. Journal of Entrepreneurship Education, 21(2), 1-15.

Riswanto, A., Hurriyati, R., Wibowo, L. A., \& Gaffar, V. (2019). Empirical Assessment of the Role of Product Innovation in Dynamic Marketing Capabilities and Company Performance. Quality-Access to Success, 20(173), 64-67.

Robbins, S.P., \& Judge, T.A. (2009). Perilaku Organisasi. Jakarta: Salemba.

Sehhat, S. et al. (2015). Positive psychological capital: The role of Islamic work ethics in Tehran Public Organizations. Iranian Journal of Management Studies, 8(4), 545-566.

Sun, Y., Jiang, H., Hwang, Y., \& Shin, D. (2018). Why should I share? An answer from personal information management and organizational citizenship behavior perspectives. Computers in Human Behavior, 87, 146-154. https://doi.org/10.1016/j.chb.2018.05.034

Suparjo., \& Sunarsih, E. S. (2018). The role of service quality and institutional image in establishing relational commitment between private universities and the student. Journal of Entrepreneurship Education, 21(3), 1-13

Szabó, Z. P., Czibor, A., Restás, P., \& Bereczkei, T. (2018). "The Darkest of all” The relationship between the Dark Triad traits and organizational citizenship behavior. Personality and Individual Differences, 134, 352-356. https://doi.org/10.1016/j.paid.2018.04.026

Triyuwono, I. (2000). Organisasi dan Akuntan Syariah. Yogyakarta: LkiS.

Tufail, M. et al. (2017). The Impact of Challenge and Hindrance Stressors on Job Satisfaction: Moderating Role of Islamic Work Ethics. Journal of Islamic Business and Management (JIBM), 7(1), 100-113. https://doi.org/10.26501/jibm/2017.0701-008

Vecchio, R. P. (2005). Organizational behavior: Core concepts. South-Western.

Wahab, M. A., Quazi, A., \& Blackman, D. (2016). Measuring and validating Islamic work value constructs: An empirical exploration using Malaysian samples. Journal of Business Research, 69(10), 4194-4204. https://doi.org/10.1016/j.jbusres.2016.03.005

Wibowo. (2014). Perilaku dalam Organisasi. Jakarta: Rajawali Pers. 